\title{
Resilience to evolving drinking water contamination risks: a human error prevention perspective
}

\author{
Yanhong Tang ${ }^{\mathrm{a}}$, Shaomin $\mathrm{Wu}^{\mathrm{b}}$, Xin Miao ${ }^{\mathrm{a}, *}$, Simon J. T. Pollard ${ }^{\mathrm{c}}$, Steve E. Hrudey ${ }^{\mathrm{d}}$ \\ ${ }^{a}$ School of Management, Harbin Institute of Technology, Harbin 150001, P.R. China \\ ${ }^{\mathrm{b}}$ Kent Business School, University of Kent, Canterbury CT2 7PE, UK \\ 'School of Applied Sciences, Cranfield University, Bedfordshire MK43 OAL, UK \\ ${ }^{\mathrm{d}}$ Environmental Toxicology Division, Faculty of Medicine \& Dentistry, University of Alberta, Edmonton T6G \\ 2G3, Canada \\ *Corresponding author: e-mail: miaoxin@hit.edu.cn, xin.miao@aliyun.com
}

\begin{abstract}
Human error contributes to one of the major causes of the prevalence of drinking water contamination incidents. It has, however, attracted insufficient attention in the cleaner production management community. This paper analyzes human error appearing in each stage of the gestation of 40 drinking water incidents and their causes, proposes resilience-based mechanisms and tools within three groups: consumers, drinking water companies, and policy regulators. The mechanism analysis involves concepts and ideas from behavioral science, organizational culture, and incentive analysis. Determinants for realizing cleaner drinking water system are identified. Future efforts and direction for embedding resilience into drinking water risk management are suggested. This paper contributes to identifying a framework and determinants of resilienceoriented management mechanisms for cleaner drinking water supply, and, is essential for ensuring the successful practice of managing drinking water contamination risks. It harmonizes the two fields of risk management and resilience thinking, and provides a new insight for implementing effective actions in drinking water-related sectors.
\end{abstract}

Keywords: drinking water incident, contamination, human error, resilience, risk management

\section{Introduction}

The drinking water utility is a typical sector that needs cleaner production. Providing wholesome, affordable and safe drinking water that has the trust of customers should be the overarching goal of the drinking water utility sector (AWWA et al., 2001; IWA et al., 2004). Therefore, drinking water utility sector is special in need of cleaner production. Interruption of water supply or deterioration of drinking water quality often leads to 
immense negative impact on people's daily living (Jalba et al., 2010). Risk management for safe drinking water is receiving increasing attention partly because drinking water disease outbreaks have been causing serious losses. Chang et al. (2012) pointed out that drinking water utilities are inherently vulnerable to contamination incidents caused by routine operations, and accordingly, proposed to develop modern concepts and approaches to risk management for these utilities. The experience of the past few decades has shown that it is not enough to merely rely on treated water compliance monitoring to ensure safe drinking water. The water sector is experiencing a significant shift in the approach from ad hoc approaches to one that increasingly manages risk explicitly and broadly (MacGillivray et al., 2007). "Process optimization, monitoring, training and management combined with improved governmental policies” (Klemeš et al., 2012) are critical contributors to clean production of drinking water.

Many papers have pay attention to cleaner production from various perspectives; however, seldom is seen to consider this aspect from human error prevention perspective. Human error plays a significant role in contributing to drinking water contamination incidents. A thorough analysis of human error in various stages of drinking water contamination incidents could be beneficial in preventing further outbreaks and ensuring cleaner drinking water supply. Here we attempt to discover potential causes of human errors in each stage of the gestation of drinking water contamination incidents and explore the potential multidimensional approaches for coping with human errors to improve the resilience of drinking water systems.

The term resilience serves as a right overarching concept to represent the idea of managing risks through prevention, reduction and mitigation. This notion includes how individuals and organizations adapt to and act on risks (Beermann, 2011). The Oxford English Dictionary defines resilience as the capacity of returning or springing back. This means in a physical sense that a system or an object can resume its initial stage or state after being displaced. Resilience is also defined as elasticity (Blackmore and Plant, 2008), and it has been referred to the art of managing unexpected, or how a team or organizations becomes prepare to cope with surprises (Attoh-Okine, 2009).

\section{Methodology}

The breakout of a drinking water contamination incident may be seen as a result of accumulation of risks from unsafe factors in a drinking water utility sector. Heinrich (1959) put forward the famous causal chain theory to explain the occurrence of an accident, which could only occur in a moment but is a consequence of a series of causalities of various factors that had occurred. Heinrich conducted a survey on 75,000 industrial accidents. The survey result showed that only $2 \%$ of these accidents cannot be prevented, and the remaining $98 \%$ can be prevented or avoid. For that $98 \%$ of all accidents, unsafe human actions accounted for the majority, that is, $88 \%$, and unsafe states of materials accounted for only $10 \%$. Furthermore, the insecurity of materials was largely caused by unsafe human actions. Therefore, Heinrich concluded that almost all accidents were caused by unsafe human actions. 
Unsafe human actions were considered as human errors in Reason's research (Reason, 2000). The famous Swiss cheese model put forward by Reason can be understood from organization management perspective. Organizational behavior plays a critical role in the risk evolution of an accident. Organization management can serve as firewalls in the risk evolution process of an accident; however, there are different degrees of vulnerability in organization management. The emergence of dynamic loopholes in the barriers formed by organization management will permit accident risks penetrating through these loopholes, especially various regulatory loopholes overlap in which risks of accidents are more likely to evolve rapidly into real emergencies. In other words, advanced organization management can serve as barriers to block risk evolution, while poor organization management will serve as booster to accelerate risk evolution. Understanding human error from organization management perspective provides significant opportunities for improving safety and promoting cleaner production for drinking water utility sector.

Based on a secondary analysis of 62 drinking water incidents occurring in affluent countries between 1974 and 2001 reported by Hrudey and Hrudey (2004), Wu et al. (2009) found that in 78\% of the 62 water incidents, human errors were direct or indirect contributors. This finding suggested "investigation of the lifecycle of drinking water incidents" as one of the pertinent areas for future research. That is, understanding the distribution of human errors across the lifecycle of drinking water incidents might help identify opportunities to reduce human errors and provide a deeper insight into their gestation.

$\mathrm{Wu}$ et al (2009) suggested that the gestation of a typical water incident might cover 6 periods: contamination, sensing, warning, recognition, inspection and recovery (Fig. 1). Analyzing human error in each period is helpful because the identification of common human errors may significantly contribute to the purposeful design of effective countermeasures. A root cause analysis may also contribute to the early discovery and reduction of potential hazards, and accordingly, reduce risks.

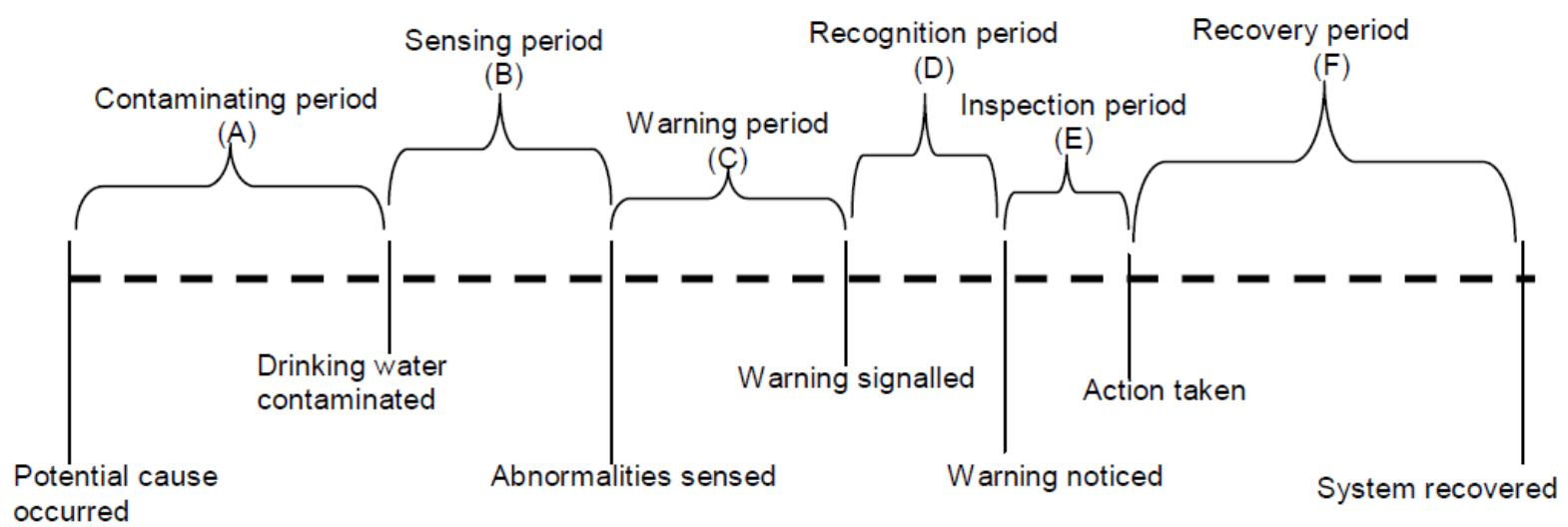

Figure 1. A typical gestation for a drinking water incident (adapted from Wu et al. (2009))

For risk evolution of drinking water contamination incidents, resilience may be considered from two perspectives, that is, how to avoid the occurrence of an incident, and how to quickly and efficiently respond to the incident, to minimize losses and social impacts it causes. Resilience can be enhanced by both risk 
reduction activities undertaken before an incident and response activities following the incident (McDaniels et al., 2008).

Human error cannot be eradicated completely because of its unpredictability and uncertainty related with human behavior. However, it is possible to reduce the probability of occurrence and the adverse consequences when it does inevitably arise (Reason, 2000). This can be achieved by improving the process of drinking water risk management to "make it hard for people to do the wrong thing and easy for people to do the right thing" (Kohn et al, 2000), and to quickly recognize unfavorable situations within the water supply system and promote its return to effective performance.

This paper completes the analysis of Wu et al (2009) through investigating 40 cases of drinking water contamination incidents by content analysis to identify typical human errors and their distributions in each period of the evolution process, proposing countermeasures to their root causes, and put forward strategies from organization management perspective for building resilience in the process management of risk evolution of drinking water contamination incidents.

\section{Material and methods}

Below, using content analysis, we reinvestigate 33 cases of drinking water incidents from Hrudey's primary analysis (Hrudey et al., 2003; Hrudey and Hrudey, 2004; Hrudey et al., 2006; Hrudey and Hrudey, 2007), and examine further 7 cases collected from other sources (Table 1).

Although we reviewed and scrutinized more than one hundred water incidents, only these 40 cases were finally chosen for analysis considering the typicality and influence of these outbreaks and incidents. Moreover, although some cases are influential, but there is insufficient official reports about the evolutive details of each stage corresponding to the typical gestation model (Wu et al., 2009), which will result in inaccuracy in distinguishing each stage shown in Figure 1. So we abandoned those cases without sufficient information in terms of the evolutive details to minimize potential author bias.

There is no doubt that the 33 cases from Hrudey's primary analysis are typical and known to many people in affluent countries. Here, we need some succinct explain about why to choose the other 7 cases. Three cases with no. 26, no. 28 and no. 36 came from renowned peer reviewed journal articles, which reported the evolutive information corresponding to Figure 1 and provide beneficial complementarities for the 33 cases from Hrudey's primary analysis, therefore, they are suitable to be adopted into this analysis. The other four cases with no. 37, no. 38, no. 39 and no. 40 came from peer reviewed journal articles and the most authoritative news agency of China. The four cases are all influential water incidents in China. Since China is the biggest developing country in the world and can be seen as a representative and pioneer of developing countries, therefore, the four cases are undoubtedly typical and have the merit to be taken into this analysis.

We categorize the human errors appearing in each evolutive stage for each drinking water incident. Human errors identified here are based on factual evidence and all the information came from referenced traceable academic literature and authoritative official reports, which contribute to minimizing potential author bias. The 
method used in this paper is not only to identify the causes of outbreaks, but highlights how human errors contribute to the amplification of the risks. The causes of drinking water incidents can be identified by other strategies such as Fault Tree Analysis, but the ordinary fault analysis techniques are not suitable to explain how a drinking water incident evolves into an influential public crisis. This paper pays attention to process analysis and try to demonstrate the role of human errors in crisis forming and risk control. So, the human error prevention perspective has not only technical significance but also social meaning and explicit policy relevance, as it contribute to precautions against the amplification of related risks.

Table 1. Drinking water incident cases and human errors in the gestation for each drinking water incident

\begin{tabular}{|c|c|c|}
\hline No. & $\begin{array}{l}\text { Incident name; Place; } \\
\text { Year }\end{array}$ & Human error sketch \\
\hline 1 & $\begin{array}{l}\text { Richmond Heights, } \\
\text { Florida, USA, } 1974\end{array}$ & $\begin{array}{l}\text { A: Pumped unchlorinated raw water to the distribution system; Less } \\
\text { consideration about pathogens; Failed to detect the invalidation of a booster } \\
\text { pump; Distributed unchlorinated groundwater to the community without } \\
\text { treatment barrier. } \\
\text { B: Lack of threat awareness about water safety; Failed to collect bacterial } \\
\text { monitoring data in January; Poor performance ability. } \\
\text { E: Public health authorities became aware only near the end of the outbreak } \\
\text { and this experience had been repeated often. }\end{array}$ \\
\hline 2 & $\begin{array}{l}\text { Rome, New York, } \\
\text { U.S.A., November } \\
\text { 1974-June } 1975\end{array}$ & $\begin{array}{l}\text { A: Insufficient drinking water filtration; failed to recognize the low level of } \\
\text { chlorination. } \\
\text { D: Ignorance of the warning inherent. }\end{array}$ \\
\hline 3 & $\begin{array}{l}\text { Camas, Washington, } \\
\text { U.S.A., April-May } \\
1976\end{array}$ & $\begin{array}{l}\text { A: Poor operating practice; Errors in drinking water system design. } \\
\text { B: No adequate monitoring program. }\end{array}$ \\
\hline 4 & $\begin{array}{l}\text { Berlin, New } \\
\text { Hampshire, USA, } \\
\text { Mar-May } 1977\end{array}$ & A: Filters shortage; Violated the health rules. \\
\hline 5 & $\begin{array}{l}\text { Bennington, Vermont, } \\
\text { USA, May } 1978\end{array}$ & A: The design of distribution system is vulnerable to contamination. \\
\hline 6 & $\begin{array}{l}\text { Bradford, } \\
\text { Pennsylvania, USA, } \\
\text { Jul-Dec } 1979\end{array}$ & $\begin{array}{l}\text { A: Chlorination is inadequate; Failed to set up adequate barriers. } \\
\text { B: Did not recognize the vulnerability of surface water sources; Routine } \\
\text { monitoring was not performed. } \\
\text { C: Little information was reported. }\end{array}$ \\
\hline
\end{tabular}




\begin{tabular}{|c|c|c|}
\hline 7 & $\begin{array}{l}\text { Georgetown, Texas, } \\
\text { USA, Jun } 1980\end{array}$ & $\begin{array}{l}\text { A: Insufficient filter operating practices; Inadequate water disposal systems. } \\
\text { B: Lack of responsiveness from the water utility; Did not recognize the } \\
\text { vulnerability of groundwater sources. } \\
\text { C: Signals from original outbreak were not recognized. } \\
\text { F: Lack of concern about groundwater sources. }\end{array}$ \\
\hline 8 & $\begin{array}{l}\text { An outbreak of } \\
\text { gastroenteritis at } \\
\text { Rome, Northern } \\
\text { Georgia, August } 1980\end{array}$ & $\begin{array}{l}\text { A: The irregularity of equipment renewal; Operation error; Coliform bacteria } \\
\text { were not quantified. } \\
\text { B: An association between illness and drinking water was not shown due to } \\
\text { low educational background (Kaplan et al., 1982); Lack of monitoring. }\end{array}$ \\
\hline 9 & $\begin{array}{l}\text { Eagle-Vail, Colorado, } \\
\text { USA, Mar } 1981\end{array}$ & $\begin{array}{l}\text { A: Operations flaw; Failed to set up adequate barriers; Insufficiency of the } \\
\text { filtration process; Unsafe maintenance work; Design errors. } \\
\text { C: Failed to survey an alarm. }\end{array}$ \\
\hline 10 & $\begin{array}{l}\text { Mjövik, Blekinge, } \\
\text { Sweden, Oct } 1982\end{array}$ & $\begin{array}{l}\text { A: Inadequate flushing of the distribution system; Maintenance errors; Lack } \\
\text { of knowledge about the drain and disinfection; Lack of understanding about } \\
\text { system. }\end{array}$ \\
\hline 11 & $\begin{array}{l}\text { Drumheller, Alberta, } \\
\text { Canada, Feb } 1983\end{array}$ & $\begin{array}{l}\text { A: Coagulation treatment in winter led to the vulnerability of water system. } \\
\text { B: Failed to perform routine monitoring; insufficient cooperation and } \\
\text { communication among various related sectors. } \\
\text { C: The notice of boil water advisory was late. } \\
\text { E: Lack of prompt investigation and remedial action. }\end{array}$ \\
\hline 12 & $\begin{array}{l}\text { Greenville, Florida, } \\
\text { USA, May } 1983\end{array}$ & $\begin{array}{l}\text { A: Employed unlicensed workers; Unsafe acts from operators; Poor design of } \\
\text { water treatment system. }\end{array}$ \\
\hline 13 & $\begin{array}{l}\text { Braun Station, Texas, } \\
\text { USA, May-Jul } 1984\end{array}$ & $\begin{array}{l}\text { A: Poorer design of the water system. } \\
\text { B: Failed to monitor water source wells. } \\
\text { F: Lack of summarization of the experience. }\end{array}$ \\
\hline 14 & $\begin{array}{l}\text { Sälen, Dalarna, } \\
\text { Sweden, Dec 1986- } \\
\text { Jan } 1987\end{array}$ & $\begin{array}{l}\text { A: Bad design of preventive backflow. } \\
\text { D: Failed to take action to alarm signals. }\end{array}$ \\
\hline 15 & $\begin{array}{l}\text { Outbreak of } \\
\text { Cryptosporidium at } \\
\text { Carrollton, Georgia, in } \\
\text { U.S.A, } 1987\end{array}$ & $\begin{array}{l}\text { A: Poor treatment practices; Delayed renewal of filtration equipment. } \\
\text { B: Malpractice of regulators; Poor design of the monitoring system. } \\
\text { E: The threat posed by pathogens was not widely recognized immediately. }\end{array}$ \\
\hline
\end{tabular}




\begin{tabular}{|c|c|c|}
\hline 16 & $\begin{array}{l}\text { Sunbury, Diggers Rest } \\
\text { and Bulla, Victoria, } \\
\text { Australia, October } \\
1987\end{array}$ & $\begin{array}{l}\text { A: Unstrained surface water was delivered to consumers; A false perspective } \\
\text { on pathogens was hold for a long time; Water quality did not satisfy the } \\
\text { standards. } \\
\text { B: Poor communication; The relevant staff did not realize heavy rainfall } \\
\text { would cause the outbreak. } \\
\text { E: Lack of trust between the water authority and investigators. }\end{array}$ \\
\hline 17 & $\begin{array}{l}\text { Cornish town Water } \\
\text { Poisoning, Camelford, } \\
\text { Britain, } 1988\end{array}$ & $\begin{array}{l}\text { A: } 20 \text { tons of aluminum sulfate was inadvertently dumped into the wrong tank } \\
\text { by a relief driver who was not familiar with the plant's layout and delivery } \\
\text { measures (Winston and Leventhal, 2008). } \\
\text { B: The driver was told to "tell no one” about the deleterious water (Cornish } \\
\text { Guardian, 2010). The cause of the problem remained undetermined for two } \\
\text { days (Winston and Leventhal, 2008). } \\
\text { C: The authority provided false information and concealed the truth; For } \\
\text { several days the water authority insisted the water was safe and revealed it } \\
\text { in a tiny advertisement in the local paper (Reid, 2007). } \\
\text { E: Lack of rigorous examination or monitoring of the health of victims; The } \\
\text { long-term implications for those victims remained unclear (Hawkes, 2006). } \\
\text { F: Related principals made irresponsible words (The Times, 1992). }\end{array}$ \\
\hline 18 & $\begin{array}{l}\text { Saltcoats/Stevenston, } \\
\text { Ayrshire, Scotland, } \\
\text { Mar-Apr } 1988\end{array}$ & $\begin{array}{l}\text { A: Lack of necessary test; Did not recognize dejecta as a pollution source; } \\
\text { Improper construction and maintenance; Failed to abide by regulations } \\
\text { B: Did not document equipment replacement; Lack of regular system audits. } \\
\text { C: Some failures were not notified timely by the system operator. }\end{array}$ \\
\hline 19 & $\begin{array}{l}\text { Skjervøy, Norway, } \\
\text { July-August } 1988\end{array}$ & $\begin{array}{l}\text { A: Unsafe acts; Lack of disinfection procedures. } \\
\text { B: Failure to perform routine monitoring. }\end{array}$ \\
\hline 20 & $\begin{array}{l}\text { Swindon, Oxfordshire } \\
\text { and Wiltshire, } \\
\text { England, } \\
\text { Dec 1988-Apr } 1989\end{array}$ & $\begin{array}{l}\text { A: Poor operating practices. } \\
\text { B: Deficiency of monitoring program. } \\
\text { C: Failed to make an explicit recommendation. }\end{array}$ \\
\hline 21 & $\begin{array}{l}\text { Moama, New South } \\
\text { Wales, Australia, } \\
\text { Dec 1989-Jan } 1990\end{array}$ & A: Maintenance error. \\
\hline 22 & $\begin{array}{l}\text { Naas, Count Kildare, } \\
\text { Ireland, Oct } 1991\end{array}$ & $\begin{array}{l}\text { A: Insufficient chlorination. } \\
\text { B: The water utility paid little attention to the initial complaint from } \\
\text { consumer. }\end{array}$ \\
\hline 23 & $\begin{array}{l}\text { Uggeløse, Denmark, } \\
\text { Dec 1991-Jan } 1992\end{array}$ & $\begin{array}{l}\text { A: Design errors; Unsafe acts. } \\
\text { C: Failed to signal warning timely when the survey result was negative. }\end{array}$ \\
\hline
\end{tabular}




\begin{tabular}{|c|c|c|}
\hline 24 & $\begin{array}{l}\text { Warrington, Cheshire, } \\
\text { England, } \\
\text { Nov 1992-Feb } 1993\end{array}$ & $\begin{array}{l}\text { B: Lack of routine monitoring; Failed to investigate the warning signals even } \\
\text { when abnormal occurred. }\end{array}$ \\
\hline 25 & $\begin{array}{l}\text { Outbreak of } \\
\text { salmonellosis in } \\
\text { Gideon, Missouri, in } \\
1993\end{array}$ & $\begin{array}{l}\text { A: Unsafe act and misconduct; no adequate monitoring program; Sanitary } \\
\text { violations; Poor maintenance. } \\
\text { B: Water quality manager was short of knowledge about the system. } \\
\text { C: Lack of enforcement; Boiling water notice was not delivered to all } \\
\text { residents. } \\
\text { F: No independent public inquiry was held; Absence of immediate record. }\end{array}$ \\
\hline 26 & $\begin{array}{l}\text { The waterborne } \\
\text { outbreak of } \\
\text { Cryptosporidiosis in } \\
\text { Milwaukee, } \\
\text { Wisconsin, } 1993\end{array}$ & $\begin{array}{l}\text { A: Failed to keep favorable filtration operation; Insufficient monitoring for } \\
\text { pathogens; Malpractice of regulators; Failed to abide by water quality } \\
\text { standards and recognize Cryptosporidium outbreaks. } \\
\text { B: Failed to respond to signals of consumer complaints; Lack of intensive } \\
\text { efforts and cooperation between the medical community and those who } \\
\text { provide and regulate drinking water (Mackenzie et al., 1994). } \\
\text { F: True reason of water pollution had never been identified and unveiled by } \\
\text { officials. } \\
\text { (summarized from Eisenberg et al., 2005) }\end{array}$ \\
\hline 27 & $\begin{array}{l}\text { Temagami, Ontario, } \\
\text { Canada, Feb-May } \\
1994\end{array}$ & $\begin{array}{l}\text { A: Poor operating ability and bad design of the water system; Poor waste } \\
\text { management; Poor performance of water-treatment plants. }\end{array}$ \\
\hline 28 & $\begin{array}{l}\text { Water contamination } \\
\text { incident near } \\
\text { Worcester, April 1994, } \\
\text { UK }\end{array}$ & $\begin{array}{l}\text { A: Unsafe acts; Lack of knowledgeable operators; Lack of the superior } \\
\text { filtration systems. } \\
\text { B: Limitation in the scale of emergency; Failure to perform routine } \\
\text { monitoring. } \\
\text { C: The delay of issuing warning; Issued inconsistent advice and list. } \\
\text { F: Short of cooperation and communication among related sectors. } \\
\text { (summarized from Fowle et al., 1996) }\end{array}$ \\
\hline 29 & $\begin{array}{l}\text { South Devon, } \\
\text { England, Aug-Sep } \\
1995\end{array}$ & $\begin{array}{l}\text { B: The operation of water treatment plant did not follow the recommendations } \\
\text { of first Badenoch Inquiry Report; Poor operation in water treatment plant. }\end{array}$ \\
\hline 30 & $\begin{array}{l}\text { Sydney Water Crisis, } \\
\text { Australia, } 1998\end{array}$ & $\begin{array}{l}\text { B: Ignorance of low levels of Cryptosporidium and Giardia; Severe } \\
\text { underestimation of the level of pathogen; Initial official inactivity. } \\
\text { C: The official issued nothing to the public about contamination. Lack of } \\
\text { appropriate contingency planning; The delay of announcing contamination. } \\
\text { D: Lack of effective education in improving compliance during boil water }\end{array}$ \\
\hline
\end{tabular}




\begin{tabular}{|c|c|c|}
\hline & & $\begin{array}{l}\text { orders; Issued three inconsistent boiled water notices that led to the distrust. } \\
\text { E: The water crisis management was improper. } \\
\text { F: The removal performance of pathogens was not specified in any contracts. }\end{array}$ \\
\hline 31 & $\begin{array}{l}\text { La Neuveville, Bern } \\
\text { Canton, Switzerland, } \\
\text { August } 1998\end{array}$ & $\begin{array}{l}\text { A: Design errors; The alarm for pump failure was shut off. } \\
\text { B: Customers failed to report abnormalities; Lack of cooperation and } \\
\text { communication between local physician and water utilities. } \\
\text { F: Water agency did not attach importance to deal with water contamination. }\end{array}$ \\
\hline 32 & $\begin{array}{l}\text { An outbreak of } \\
\text { gastroenteritis at } \\
\text { Resort Hotel in } \\
\text { Bermuda, Feb } 1998\end{array}$ & $\begin{array}{l}\text { A: The water tank was not cleaned; Poor maintenance; Lack of } \\
\text { communication between various parties; Unsafe maintenance; The system } \\
\text { vulnerability was not recognized; Lack of operator training and } \\
\text { management liability; Poor design in drainage system; Sanitary deficiencies } \\
\text { of chlorinated water system. } \\
\text { B: Lack of regular monitoring. } \\
\text { F: Lack of an international guideline for the management of water incidents } \\
\text { among tourists in holiday resorts (Jiménez et al., 2004). }\end{array}$ \\
\hline 33 & $\begin{array}{l}\text { Outbreak of } \\
\text { Escherichia coli } \\
\text { O157:H7 and } \\
\text { Campylobacter among } \\
\text { attendees of the } \\
\text { Washington County } \\
\text { Fair, New York, } 1999\end{array}$ & $\begin{array}{l}\text { A: Lack of flushing and disinfection program; Unsafe acts; Failed to } \\
\text { recognize risk from septic seepage; No one realized that the extreme } \\
\text { drought of previous summer might induce unsafe water; Narrowly relying } \\
\text { on monitoring to assure safety. } \\
\text { B: Inadequacy of intermittent microbiological monitoring of wells. }\end{array}$ \\
\hline 34 & $\begin{array}{l}\text { Walkerton Ontario } \\
\text { Canada, } 2000\end{array}$ & $\begin{array}{l}\text { A: Paid less attention to the protective advice for water source at installation } \\
\text { stage; Design errors; maintenance errors; Less training for frontline } \\
\text { workers; Did not realize the extreme weather might affect water safety; } \\
\text { Narrowly relying on monitoring as indicators to assure safety; Ignored } \\
\text { warning signals of shallow well vulnerability. } \\
\text { B: Regulator failed to meet regulations with continuous monitoring of } \\
\text { chlorine residual to vulnerable shallow wells. } \\
\text { C: Lack of procedures for giving out information; Manager fails to notify } \\
\text { involved parties. } \\
\text { E: The utility does not conduct on-the-spot investigations. } \\
\text { F: The simplified reporting mechanism did not include the requirement of } \\
\text { reporting adverse test results. }\end{array}$ \\
\hline
\end{tabular}




\begin{tabular}{|c|c|c|}
\hline 35 & $\begin{array}{l}\text { North Battleford, } \\
\text { Canada, Mar-April } \\
2001\end{array}$ & $\begin{array}{l}\text { A: Poor water treatment performance; Lack of competent foreman; Unsafe } \\
\text { acts; Outdated technology; Limited operator training; Lack of real-time } \\
\text { feedback in Info System; Lack of continuing education and training of } \\
\text { operators; Lack of a network for sharing experience and learning from } \\
\text { others; No reservoir for water treatment; Narrowly relying on monitoring as } \\
\text { indicators to assure safety; Ignored warnings about vulnerability of shallow } \\
\text { well. } \\
\text { B: Inadequate supervision of waterworks; Negative respond to operator’s } \\
\text { report. } \\
\text { C: No further inspection after sensing abnormality. } \\
\text { E: Ambiguous CDI guidance. }\end{array}$ \\
\hline 36 & $\begin{array}{l}\text { Transtrand, Dalarna, } \\
\text { Sweden, February- } \\
\text { March } 2002\end{array}$ & $\begin{array}{l}\text { A: Lack of chlorination for drinking water supply. } \\
\text { C: Boil water notice was issued late. } \\
\text { D: Lack of effective response. } \\
\text { (summarized from Carrique-Mas et al., 2003; Westrell et al., 2006) }\end{array}$ \\
\hline 37 & $\begin{array}{l}\text { Harbin Water Crisis, } \\
\text { Heilongjiang } \\
\text { Province, China, } \\
\text { November } 2005\end{array}$ & $\begin{array}{l}\text { A: Unsafe acts; Maintenance error. } \\
\text { B: Concealed the truth; No communication between government and the } \\
\text { public. } \\
\text { C: Concealed the truth; Late warning; Delay in releasing the fact. } \\
\text { E: Dissemination of pollution information by media was governed. } \\
\text { F: Lack of the cooperation among the actors; Unclear of liability; Lack of an } \\
\text { authoritative crisis management department. } \\
\text { (summarized from Xinhua News Agency, 2005) }\end{array}$ \\
\hline 38 & $\begin{array}{l}\text { Wuxi water crisis, } \\
\text { Jiangsu, China, } 2007\end{array}$ & $\begin{array}{l}\text { A: Poor site selection of plant location; Extreme eutrophication and improper } \\
\text { discharge of industrial and domestic wastewater. } \\
\text { B: Failed to recognize extreme weather could cause water contamination. } \\
\text { (summarized from Zhang et al., 2010) }\end{array}$ \\
\hline 39 & $\begin{array}{l}\text { Shuyang } 40 \text { hours } \\
\text { water crisis, Jiangsu } \\
\text { Province, China, July } \\
2007\end{array}$ & $\begin{array}{l}\text { A: Unsafe acts; Maintenance error. } \\
\text { (summarized from Xinhua News Agency, 2007) }\end{array}$ \\
\hline 40 & $\begin{array}{l}\text { Chifeng water } \\
\text { pollution, Inner } \\
\text { Mongolia, China, } \\
\text { July- August } 2009\end{array}$ & $\begin{array}{l}\text { A: Lack of security safeguard; Unsafe performance acts. } \\
\text { B: No aware of fecal contamination around the surface water; Lack of water } \\
\text { plant experience; Negligence of related departments. } \\
\text { C: Late notification; Delay in reporting water pollution. } \\
\text { F: Late remedial measures; Underestimation of the water pollution }\end{array}$ \\
\hline
\end{tabular}




\begin{tabular}{l|l|c}
\hline & $\begin{array}{c}\text { consequences; Lack of subsequent remedy. } \\
\text { (summarized from Xinhua News Agency, 2009) }\end{array}$ \\
\hline
\end{tabular}

Table 1 provides cases in which human error directly or indirectly contributes to drinking water incidents. These cases show that human error may occur in any period of a water incident gestation process. Table 2 summarizes human errors in different periods of the gestation process with indication of corresponding case numbers. Figure 2 summarizes the accumulative number of human errors in Table 2 corresponding to each digestion period in Figure 1.

Table 2. Summary of different types of human errors emerged in different digestion periods

\begin{tabular}{|c|c|}
\hline Human errors & Corresponding period and serial number of cases \\
\hline Unsafe acts. & $\begin{array}{l}\text { A: } 1,2,7,8,9,12,15,16,17,18,19,23,25,26,28,31,32,33,34 \text {, } \\
35,37,38,39,40\end{array}$ \\
\hline Design errors. & $\begin{array}{l}\text { A: } 5,9,13,14,22,23,27,31,32,34,35,36,38 \\
\text { B: } 15\end{array}$ \\
\hline Maintenance errors. & $\begin{array}{l}\text { A: } 1,4,9,10,15,16,18,21,25,26,27,28,32,34,35,37,39 \\
\text { B: } 18\end{array}$ \\
\hline Poor operation skills. & A: $1,2,3,6,7,8,9,10,11,12,15,20,22,27,32,33,34,35,40$ \\
\hline $\begin{array}{l}\text { Failed to recognize external changes that may cause } \\
\text { water contamination. }\end{array}$ & B: $1,6,7,16,18,33,34,38,40$ \\
\hline Failure to perform routine monitoring. & B: $1,3,6,8,11,13,18,19,20,24,25,26,28,32,33,34,35$ \\
\hline Failure to interpret monitoring results correctly. & B: $8,13,30$ \\
\hline Failure to respond to reports of consumers or others. & $\begin{array}{l}\text { B: } 7,22,26,29,35 \text {, } \\
\text { D: } 2\end{array}$ \\
\hline $\begin{array}{l}\text { Warning signals are absent, inadequate, late, } \\
\text { inconsistent or misdirecting. }\end{array}$ & C: $6,7,9,11,17,18,20,23,25,28,30,34,35,36,37,40$ \\
\hline Failure to or inadequate respond to warnings. & D: $14,30,36$ \\
\hline Poor emergency response. & $\begin{array}{l}\text { E: } 11,30,34,37 \\
F: 17,25,31,32,34,37,40\end{array}$ \\
\hline Lack of communication or trust. & $\begin{array}{l}\text { B: } 11,16,26,31,37 \\
C: 30,34 \\
E: 15,16 \\
F: 28,37\end{array}$ \\
\hline Disguise, underestimate, denial or contempt. & $\begin{array}{l}\text { B: } 17,34,37 \\
C: 17,30,37 \\
E: 1,17,30,35,37 \\
F: 7,13,26,30,34,40\end{array}$ \\
\hline
\end{tabular}




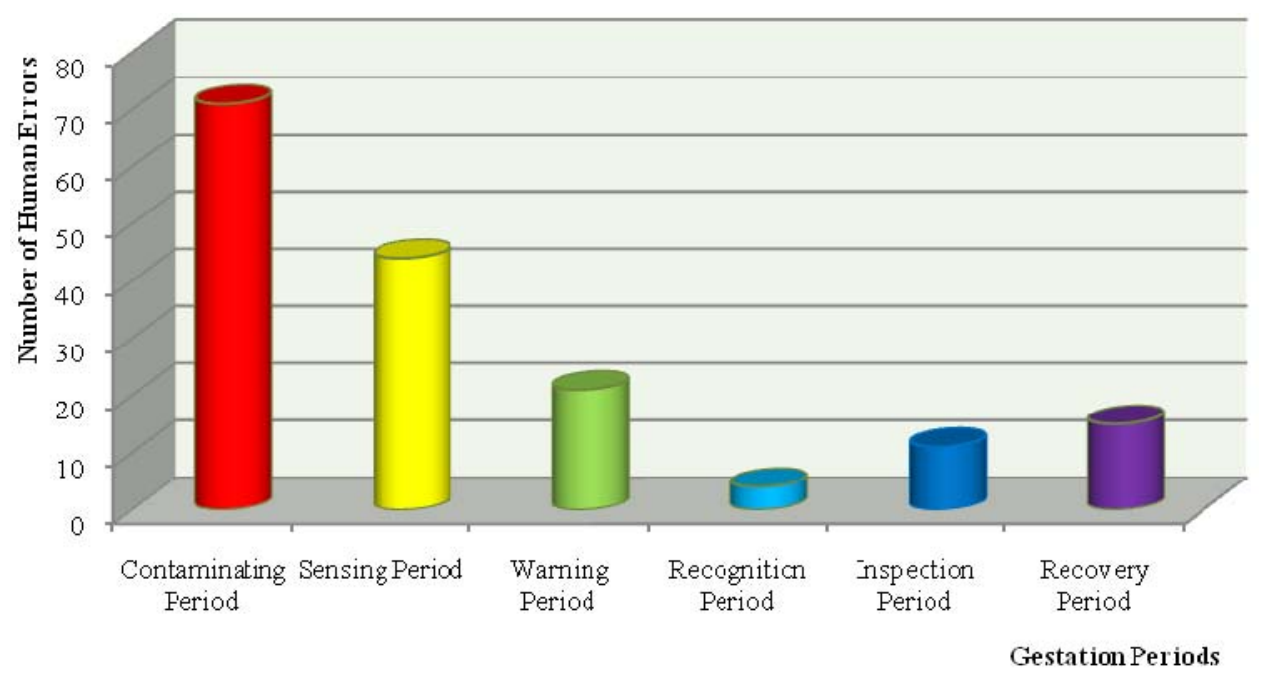

Figure 2. The accumulative number of human errors for each period (investigated from the 40 cases)

Figure 2 illustrates that the contamination period has the most frequent occurrence of human errors and the sensing period is also significant. The occurrence of human errors in the other periods (warning, recognition, inspection and recovery) is less frequent but cannot be ignored. Consequently, we speculate that human errors contribute significantly to allowing a potential water hazard to evolve into a severe water incident, and it is therefore imperative to distinguish and further control human errors in the early stages of a drinking water incident.

\section{Results and analysis}

\subsection{The distribution of the human errors in each period}

From Table 2, we can obtain the distribution of the human errors in each period, as Figure 3 shows: 


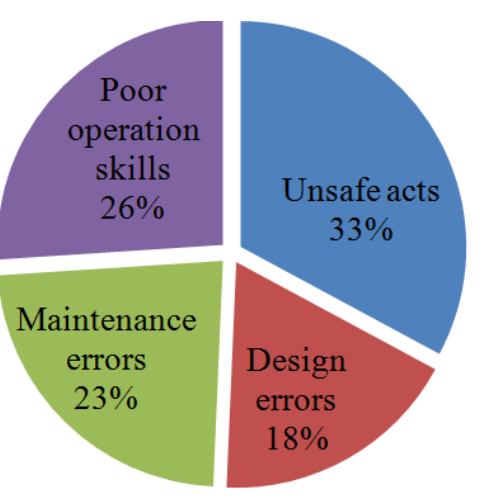

Contaminating Period

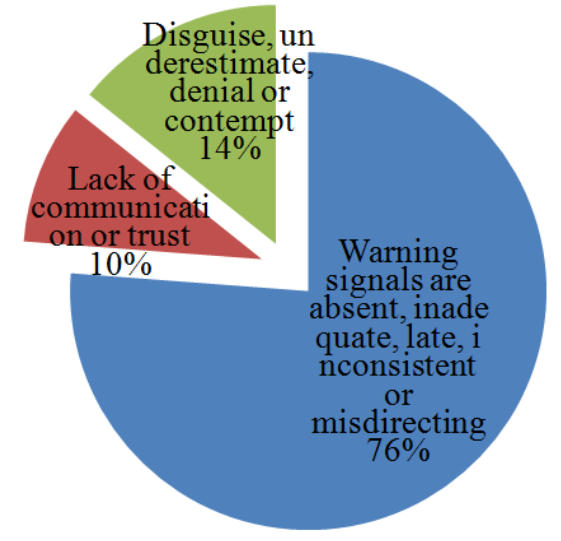

Warning Period

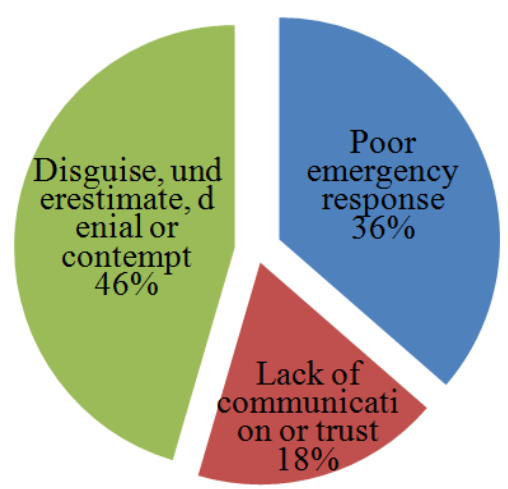

Inspection Period

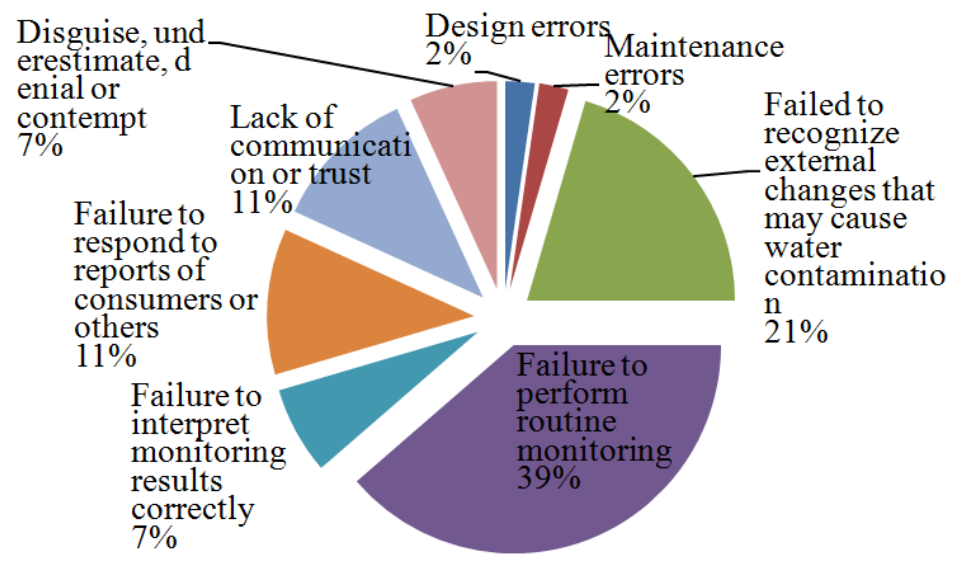

Sensing Period

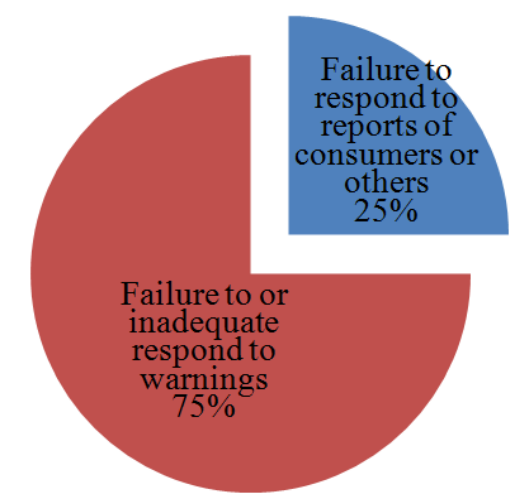

Recognition Period
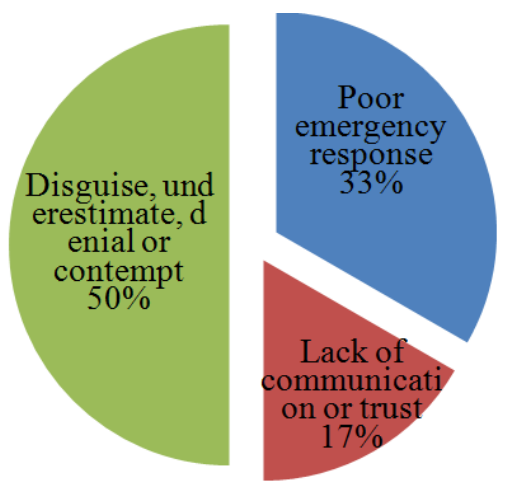

Recovery Period

Figure 3. The distribution of the human errors in each period

\subsection{Commonalities and potential countermeasures in each period}

\subsubsection{Contaminating period}

We categorize human errors in the contamination period fall into four types: unsafe acts, design errors, maintenance errors and poor operational skills. These errors are mostly related to the behavior of operators and 
managers. Organizations in case studies 2, 8, and 9 lacked safety rules and operating procedures. Frontline workers in cases 1, 16 and 34 were remiss in their work and malpractice resulted in drinking water incidents. For these situations, standard operating procedures (SOP) must be reinforced and effectively implemented. A SOP is a set of written documents or instructions detailing all necessary steps of a routine or repetitive activity which should be followed by an organization (United States Environmental Protection Agency, 2007). SOPs are important to drinking water management and can facilitate consistent service quality. SOPs recount the regular performance processes implemented or followed in a drinking water supply system, and include procedures that can be performed to promote consistency of technical and quality requests for drinking water supply. In addition, SOPs involve fundamental performance actions and technical-related operations. However, SOPs must be followed strictly and SOPs must also be continuously improved based on experience. Learning from the past is an essential and effective way for building resilience to secure safe drinking water. For poor operational skills, a preferred way is to employ well-educated operators. If this cannot be achieved, sufficient in-house training must be provided by drinking water utilities and its effectiveness must be evaluated.

\subsubsection{Sensing period}

Human errors are colorful in terms of various types in the sensing period. The sensing period is critical because early detection of contamination offers a chance for rapid and effective emergency response. It is a critical period for demonstrating resilience. Failure to perform routine monitoring effectively is the principal human error in this period. Incentives are needed to promote safety consciousness among operators and monitoring personnel. Rigorous penalty clauses in addition to specific rewards are necessary to guarantee effective current monitoring. Inexperience or lack of concern will naturally lead to a "failure to interpret monitoring results correctly". A related human error is a failure "to recognize external changes that may cause water contamination". This may be caused by external uncertainties about threats to the safety of drinking water and/or workers' lack of attention, care or devotion to their work. Therefore, training, education and incentives for good performance are essential. Likewise, financial support and managers' commitment must be sufficient to build efficient reporting and communication channels for rapid recognition of drinking water abnormalities. The "failure to respond to reports of consumers or others" and "lack of communication" also constitute a large part of human error in this period of the evolution of incidents.

\subsubsection{Warning period}

Rapid and efficient warning is essential for preventing a water crisis and minimizing the potential losses. Any obstacle that leads to insufficient or inefficient warning may allow consequences to escalate. In the warning period, water companies examined in these studies often failed to provide timely and reliable warning information, where missing is an important factor contributing to the deterioration of the situation. In fact, all of the human errors found in the warning period showed that warning signals were not properly delivered to the consumers. The reasons were diverse, but the common theme was the need to advise consumers as accurately and as soon as possible about what consumers can and should do. A functional and collaborative 
relationship with the relevant public health agency should be a high priority for a water provider (Jalba et al., 2010).

\subsubsection{Recognition period}

Human errors in the recognition period were comparatively rare. Only 4 out of the total of 40 cases exhibit human errors in this period. But the role of this period should not be neglected. Extensive and clear notices are necessary to make consumers recognize what is wrong with the tap water and how to cope with the difficult period when safe drinking water is not provided. Most strategies in the recognition period aim to reduce the impacts of the drinking water incident and minimize adverse consequences. Techniques like an official email notice and/or Short Message Service (SMS) will help the public to understand the emergency situation quickly. Further information and progress may properly be provided by local radio, TV and online news.

\subsubsection{Inspection period and recovery period}

The inspection period and recovery period exhibit similar types of human errors. "Poor emergency response" is typical in the above two periods. Collaboration of different departments, cultivation of emergency leadership and learning from past incidents are important to enhance the emergency response ability (Jalba et al., 2010). From the case studies, deficiencies revealed by "lack of communication or trust" and "conceal the fact or tell lies" are likely to arise in various stages of different drinking water incidents. These errors must be eradicated by effective management mechanisms.

\section{Discussion}

There are some commonalities among the drinking water incidents we analyzed. For example, early identification and swift response in these cases were frequently absent; frontline workers lacked a sense of responsibility and were inadequately trained; and consumers, as the front line for sensing abnormalities, lacked an effective channel for reporting, complaining and communication about their detection of drinking water contamination. This deficiency leads to delays in taking countermeasures to control contamination and results in risk amplification to cause a water crisis with even greater negative social impacts.

Early identification of hazards is important to prevent and control water incidents, and this rests with the persistence and maintenance of a culture of trust, integrity, cooperation and open communication between users and providers of drinking water. If an error is made and recognized, initiatively admitting and quickly reporting it to an appropriate supervisor will be the right thing. In contrast, hiding or ignoring errors is likely to lead to serious consequences (Johnstone and Kanitsaki, 2006). An effective system will allow operational personnel to recognize when they are facing a situation which may exceed their capacity to respond effectively and encourage them to seek assistance in dealing with the problem.

Given the need for coping with human errors to secure safe drinking water, the following discusses approaches and tools to achieve resilience by considering three groups: consumers, drinking water companies, 
and policy regulators. This analysis involves concepts and ideas from behavioral science, organizational culture, and incentive analysis. The following will clarify this step by step.

\subsection{Seeking resilience through active consumer complain channels}

Consumers are in the frontline of using tap water and this position provides them the chance to discover abnormal taste in drinking water. It is essential for the warning alarms signaled by consumers to be effectively heard by the water supply company. Paying more attention to complaints from consumers can be helpful for improving management, maintenance and monitoring of drinking water quality (Montenegro et al., 2009). But we should also notice, as da Silva et al. (2010) highlighted, that assuring citizen rights and company obligations in monitoring drinking water safety and reporting abnormality is hindered by poor channels of communication. Meyer-Emerick (2004) believed that the communication supported by the Consumer Confidence Reports (CCRs) was one-way, and water companies should communicate with their consumers routinely in a two-way dialog capable of listening to the questions and concerns of consumers. Perceptions of taste and odour problems should be recognized as a critical issue. But historically, drinking water providers seldom set a high priority on facilitating users' communication with them.

A key factor for building resilience mechanisms to cope with human error in drinking water systems is assuring a swift response to customer complaints, which is efficient for recovery from a specific or immediate malfunction and helpful for the quick identification of human error to reduce the likelihood of a serious water incident. Resilience mechanisms should include facilitation of consumer complaints, the ability to respond to complaints in a timely manner, and the ability to quickly recover from incidents. But most consumers who complained tend to transfer information informally only to frontline operators, neighbors, anyone easy to access, rather than to responsible authorities. Central in this regard are findings by the Technical Assistance Research Programs that show a "tip of the iceberg" phenomenon for complaints (Goodman, 1999). In particular, across incidents, of those who had reasons for complaint, only about $1 \%$ to $5 \%$ complained to principal managers; about $45 \%$ complained to frontline operators, though such complaints seldom reached principal managers; and about 50\% who encountered negative events never complained (Luria et al., 2009). This phenomenon is understandable because customers wish to quickly address their immediate concerns and are intended in obtaining a swift response (Bettencourt and Brown, 2003). Informal complaints from consumers may obtain a quick answer only if frontline operators are appropriately empowered, well educated, trained and supported (Homburg and Fürst 2005). Unfortunately, informal complaints are less likely to be heard by the right managers unless frontline operators are motivated to report them upwards or consult with immediate supervisors about how to deal with them (Luria et al., 2009). It is thus essential to encourage consumers and frontline operators to report abnormality, and make quick responses to emerging problems. This motivation requires cultivation of a safety culture.

\subsection{Building resilience through cultivating safety culture}


The concept of "safety culture", usually referred to as safety knowledge or safety consciousness formed in social practice, was put forward by the International Nuclear Safety Advisory Group (INSAG, 1986). It differs from the common "culture" concept.

Safety culture for a water utility might involve two aspects. (1) It is embedded in organizational attitudes and values, reflecting a common sense of a drinking water supply enterprise and its employees about the importance of safety and security. It requires staff to put safety above all else in their work, especially when the economic benefits and security considerations are in conflict, to ensure the safe drinking water prevails. (2) It is also related to personal attitude, which reflects personal awareness of security-related institutions, measures and behaviors and personal feelings about security. The key points of building safety culture lie in: the philosophy of safety first, recognition that everyone is a barrier to preventing a water incident, a high degree of transparency, and a culture promoting feedback from experience which also actively encourages discovery of problems. In the process of cultivating a safety culture, the following key measures are suggested:

- Establish a sound security management unit inside the drinking water agency that will develop internal security policies, objectives, regulations and quality management procedures.

- Develop a quantitative evaluation index system for safety culture based on a Management by Objectives (MBO) approach, with reference to the practice of the agency itself.

- Ensure that managers set a consistently good example for the sake of safety management.

- Enhance training and improve technical skills and awareness of safety culture among first-line operators, and at the same time, establish strict safety standards for critical actions and procedures.

- Trace the root causes of past incidents and learn from past events.

- Build an ongoing self-assessment system for safety culture and improve it continually.

- Create and maintain a healthy atmosphere for receiving customers' opinions through extensive publicity of safety culture.

Safety culture needs to be an important element of modern management of drinking water supply enterprises. This culture will establish a set of scientific and strict rules and regulations, cultivate staff security consciousness and good working habits, and create an atmosphere whereby everyone is concerned about the drinking water safety. Safety culture plays an important active role in reducing human errors and raising the level of overall security and is an effective contribution towards building resilience.

The foregoing proposals about cultivating safety culture are based on the assumption that a drinking water supply corporation has active motivation, strong will and thorough determination to put drinking water safety above all other considerations. However, many water supply corporations may fail to create safety culture for different reasons. Therefore, it is better to introduce an incentive compatibility mechanism (Miao et al., 2010) to direct the behaviors of local government, water supply agencies and employees to force implementation of thorough supervision of drinking water by forming multi-level restrictions, rewards and disciplinary rules. But the local government should not confine its role in setting rules. It should commit itself to create a risk control oriented institutional culture and to provide all the possible support to facilitate the achievement of this 
ambition (Labodova, 2004). In this manner, resilience can be built effectively and problems can be brought to the surface and solved to their root causes, providing a feasible and efficient way for securing safe drinking water.

\subsection{Developing resilience through collaboration}

Table 3 characterizes the strategies that have a high probability of developing resilience through collaboration to cope with human errors and potential risks in drinking water systems.

Table 3. Strategies for developing resilience through collaboration to cope with human errors

\begin{tabular}{|c|c|}
\hline & \\
\hline Comm & $\begin{array}{l}\text { By communicating the abnormality of drinking water quality among various parties, } \\
\text { an effective and immediate response may be performed. The communication, as } \\
\text { mentioned above, is critical in understanding actual local impacts and adaptations and } \\
\text { has high probability for reducing or reversing adverse consequences (Berkes, 2007). }\end{array}$ \\
\hline ing & $\begin{array}{l}\text { Frontline operators, immediate managers, supervisors, water utilities and government } \\
\text { agencies should learn from past drinking water events. If do not learn or summarize } \\
\text { the experience and lessons from past incidents, it is possible that the disaster will } \\
\text { repeat again. On the contrary, there will be an opportunity to get a clear understanding } \\
\text { of the situation. Drinking water utilities have the opportunity to create learning } \\
\text { networks across stakeholders such as policy-makers, supervisors, operators, local } \\
\text { physicians and consumers (Ullsten et al., 2004). }\end{array}$ \\
\hline $\begin{array}{l}\text { Inter-organization } \\
\text { cooperation }\end{array}$ & $\begin{array}{l}\text { A treaty of collaboration among related departments should be reached (such as a } \\
\text { treaty between local physician and water company). This can further strengthen } \\
\text { organizational incentive effect and enhance response speed in coping with drinking } \\
\text { water incidents and reducing the severity of an incident. }\end{array}$ \\
\hline $\begin{array}{l}\text { Information platform } \\
\text { facilitated by ICT } \\
\text { (Information and } \\
\text { Communication } \\
\text { Technology) }\end{array}$ & $\begin{array}{l}\text { After recognizing the abnormality of drinking water, Information platform facilitated } \\
\text { by ICT provides an efficient platform to promote communication among the front-line } \\
\text { operators, local physicians, municipal governors and the relevant water utility } \\
\text { departments. This can greatly simplify the procedure of abnormality report process } \\
\text { and enhance the speed of emergency response. }\end{array}$ \\
\hline
\end{tabular}

With the adoption of the recommended strategies, human errors and potential risks in drinking water system may be dramatically reduced. It should be noted that the feasibility of these strategies should be guaranteed by designing incentive compatibility mechanisms (Miao et al., 2010) to drive the collaboration of related actors 
(Zeng et al., 2011). Furthermore, various tactics can be further developed to make these strategies suitable for concrete scenarios.

\subsection{Enhancing resilience through preventive risk management tools}

Preventive risk management has tools based on resilience philosophy. For example, we list two:

- Critical Control Points (CCPs). CCPs are critical for ensuring safe drinking water safety from source contamination to distribution. CCPs can be developed by obtaining thorough understanding of the drinking water treatment processes. Knowledge management, expert insight and experience, and staff training need to safeguard CCPs. Ongoing, thorough inspection is necessary to detect all the relevant hazards that may threaten CCPs, and this compromise preventative risk management.

- SOPs. These are vital for preventing human errors. SOPs contribute to confirming the desired workflow and avoiding possible trouble that may lead to avoidable risks. Human reliability analysis designs a process that is easy for personnel to do the right thing and hard to do the wrong thing (BostonFleischhauer, 2008) making SOPs imperative for enhancing human reliability and reducing human errors.

Although the issue of safe drinking water has been given increasing attention and is perceived to be desirable by society, achievement of the safety goal is very difficult. Overcoming the challenge of human errors calls for culture-related organizational change, which is critical for embedding resilience into drinking water risk management. However, organizational culture is implicitly woven into everyday corporate practice, and is extremely difficult to be changed at its root. This challenge poses an agenda for further exploration. For instance, identifying and understanding an agency's existing safety culture will reveal fields that need change; distinguish and cultivate the appropriate leadership style in water risk management to promote culture change (Summerill et al., 2010); discover communication barriers and build efficient reporting channels for abnormal conditions; find ways to improve team cohesiveness and staff motivation; enhance organizational learning and flexibility. Besides, detailed comparative case study may be further developed to analyze the difference in risk management for point- and area- water pollution.

\section{Conclusions}

This paper finds that human error is a major contributor to risk amplification of drinking water incidents. Understanding and taking actions to prevent human errors across the lifecycle of drinking water incidents closely relates to the concept of resilience in drinking water risk management. In view of many potential causes of drinking water incidents, resilience makes a useful intellectual and policy contribution to find means to cope with the situations under which drinking water incidents might happen. It will not be possible to remove all potential factors and conditions that may allow human error, and no water agency can guarantee that breakdowns will not occur. However, management of human error is a comprehensive process involving 
prevention, planning, acute response, recovery and learning. All of these procedures involve resilience, a beneficial insight about drinking water safety that shifts from a traditional human reliability perspective to viewing organization as a defense against failure. Translating the resilience concept into practice requires identifying and testing mechanisms for constructing resilience within complex process reengineering. This study suggests that an effective and immediate response during the immediate aftermath (the first hours and days) critically relies on the resilience developed with consumers, first-line responders, water supply agency and local government.

\section{Acknowledgements}

This research is supported by the National Natural Science Foundation of China (Grant No. 71101036, Grant No. 61074133), the Research Fund for the Doctoral Program of Higher Education (Grant No. 20112302120037), the Fundamental Research Funds for the Central Universities (Grant No. HIT.NSRIF.2010082, Grant No. HIT.BRETIII.201208), the Humanities and Social Sciences Fund of the Chinese Ministry of Education (Grant No. 09YJC630049) and the Natural Science Foundation of Heilongjiang Province (Grant No. G201014).

\section{References}

Attoh-Okine, N.A., 2009. Editorial. IEEE Syst. J. 3 (2), 146.

AWWA, EUREAU, WSAA, DVGW. 2001. Bonn Workshop 2001 - Key principles in establishing a framework for assuring the quality of drinking water: a summary. AWWA, Denver, CO.

Beermann, M., 2011. Linking corporate climate adaptation strategies with resilience thinking. J. Clean Prod. 19 (8), $836-842$.

Berkes, F., 2007. Understanding uncertainty and reducing vulnerability: lessons from resilience thinking. Nat. Hazards 41 (2), 283-295.

Bettencourt, L.A., Brown, S.W., 2003. Role stressors and customer-oriented boundary-spanning behaviours in service organizations. J. Acad. Mark. Sci. 31 (4), 394-408.

Blackmore, J.M., Plant, R.A.J., 2008. Risk and resilience to enhance sustainability with application to urban water systems. J. Water Resour. Plan. Manage. - ASCE 134 (3), 224-233.

Boston-Fleischhauer, C., 2008. Enhancing healthcare process design with human factors engineering and reliability science, part 2 - applying the knowledge to clinical documentation systems. J. Nurs. Adm. 38 (2), 84-89.

Carrique-Mas, J., Andersson, Y., Petersen, B., Hedlund, K.O., Sjogren, N., Giesecke, J. 2003. A Norwalk-like virus waterborne community outbreak in a Swedish village during peak holiday season. Epidemiol. Infect. 131 (1), 737-744.

Chang, N.B., Pongsanone, N.P., Ernest, A. 2012. A rule-based decision support system for sensor deployment in small drinking water networks. J. Clean Prod. 29-30, 28-37.

Cornish Guardian. 2010. Driver was told to 'tell no one' about poisoning. Available at: http://www.highbeam.com/doc/1P226109748.html (accessed 21/05/2011).

da Silva, S.R., Heller, L., Valadares, J.D., Cairncross, S., 2010. Relationship (or its lack) between population and a water and sanitation service: a study of users' perception in Vitoria (ES) Brazil. J. Water Health 8(4), 764-778. 
Eisenberg, J.N.S., Lei, X.D., Hubbard, A.H., Brookhart, M.A., Colford, J.M. 2005, The role of disease transmission and conferred immunity in outbreaks: analysis of the 1993 Cryptosporidium outbreak in Milwaukee, Wisconsin. Am. J. Epidemiol. 161 (1), 62-72.

Fowle, S.E., Constantine, C.E., Fone, D., McCloskey, B. 1996. An epidemiological study after a water contamination incident near Worcester, England in April 1994. J. Epidemiol. Community Health 50 (1), 18-23.

Goodman, J. 1999, Basic facts on customer complaint behavior and the impact of service on the bottom line. Compet. Advant., pp. $1-5$.

Hawkes, N. 2006. Alzheimer's linked to aluminium pollution in tap water. The Times. Available at: http://www.timesonline.co.uk/tol/news/uk/health/article707311.ece (accessed 21/05/2011).

Heinrich, HW. 1959. Industrial Accident Prevention. McGraw-Hill Inc., US.

Homburg, C., Fürst, A., 2005. How organizational complaint handling drives customer loyalty: an analysis of the mechanistic and the organic approach. J. Mark. 69 (3), 95-114.

Hrudey, S.E., Hrudey, E.J., 2004. Safe Drinking Water-Lessons from Recent Outbreaks in Affluent Nations. IWA Publishing, London, UK.

Hrudey, S.E., Hrudey, E.J., 2007. Published case studies of waterborne disease outbreaks - evidence of a recurrent threat. Water Environ. Res. 79 (3), 233-245.

Hrudey, S.E., Hrudey, E.J., Pollard, S.J.T., 2006. Risk management for assuring safe drinking water. Environ. Int. 32 (8), $948-$ 957.

Hrudey, S.E., Payment, P., Huck, P.M., Gillham, R.W., Hrudey, E.J., 2003, A fatal waterborne disease epidemic in Walkerton, Ontario: comparison with other waterborne outbreaks in the developed world. Water Sci. Technol. 47 (3), 7-14.

International Nuclear Safety Advisory Group. 1986. Summary Report on the Post-Accident Review Meeting on the Chernobyl Accident. Report No. 75-INSAG-1, Safety Series.

IWA. 2004, The Bonn Charter. International Water Association, London, Available at: www.iwahq.org/uploads/bonn\%20charter/BonnCharter.pdf (accessed 21/05/2011).

Jalba, D.I., Cromar, N.J., Pollard, S.J.T., Charrois, J.W., Bradshaw, R., Hrudey, S.E., 2010. Safe drinking water: critical components of effective inter-agency relationships. Environ. Int. 36 (1), 51-59.

Johnstone, M.J., Kanitsaki, O., 2006. The ethics and practical importance of defining, distinguishing and disclosing nursing errors: a discussion paper. Int. J. Nurs. Stud. 43 (3), 367-376.

Kaplan, J.E., Goodman, R.A., Schonberger, L.B., Lippy, E.C., Gary, G.W., 1982. Gastroenteritis due to norwalk virus - an outbreak associated with a municipal water-system. J. Infect. Dis. 146 (2), 190-197.

Klemeš, J.J., Varbanov, P.S., Huisingh, D. 2012. Recent cleaner production advances in process monitoring and optimization. J. Clean Prod. 34 (SI), 1-8.

Kohn, L., Corrigan, J., Donaldson, M., Eds. 2000. To Err is Human: Building a Safer Health System, National Academy Press: Washington DC.

Labodova, A. 2004. Implementing integrated management systems using a risk analysis based approach. J. Clean Prod. 12 (6), 571-580.

Luria, G., Gal, I., Yagil, D., 2009. Employees' willingness to report service complaints. J. Serv. Res. 12 (2): 156-174.

MacGillivray, B.H., Sharp, J.V., Strutt, J.E., Hamilton, P.D., Pollard, S.J.T., 2007. Benchmarking risk management within the international water utility sector. Part II: A survey of eight water utilities. J. Risk Res. 10 (1), 105-123.

Mackenzie, W.R., Hoxie, N.J., Proctor, M.E., Gradus, M.S., Blair, K.A., Peterson, D.E., Kazmierczak, J.J., Addiss, D.G., Fox, K.R., Rose, J.B., Davis, J.P., 1994. A massive outbreak in Milwaukee of Cryptosporidium infection transmitted through the public water-supply. N. Engl. J. Med. 331 (3), 161-167. 
McDaniels, T., Chang, S., Cole, D., Mikawoz, J., Longstaff, H. 2008. Fostering resilience to extreme events within infrastructure systems: characterizing decision contexts for mitigation and adaptation. Global Environ. Chang. 18 (2), 310-318.

Meyer-Emerick, N., 2004. Are we answering the right questions? Improving CCR communication. J. Am. Water Works Assoc. 96 (8), 104-111.

Miao, X., Yu, B., Xi, B., Tang, Y.H. 2010. Modeling of bilevel games and incentives for sustainable critical infrastructure system. Technol. Econ. Dev. Econ. 16(3), 365-379.

Montenegro, P., Rodriguez, M.J., Miranda, L., Joerin, F., Proulx, F. 2009. Occurrence of citizen complaints concerning drinking water: a case study in Quebec City. J. Water Supply Res. T. 58 (4), 257-266.

Páez Jiménez, A., Pimentel, R., Martínez de Aragón, M.V., Hernández Pezzi, G., Mateo Ontañon, S., Martínez Navarro, J.F., 2004. Waterborne outbreak among Spanish tourists in a holiday resort in the dominican republic. Euro Surveill 9 (3), 21-23.

Reason, J., 2000. Human error: models and management. Brit. Med. J. 320 (7237), 768-770.

Reid, S. 2007. A lethal cover up: Britain's worst water poisoning scandal. Available at: http://www.dailymail.co.uk/news/article502442/A-lethal-cover-Britains-worst-water-poisoning-scandal.html (accessed 20/04/2013).

Summerill, C., Pollard, S.J.T., Smith, J.A. 2010. The role of organizational culture and leadership in water safety plan implementation for improved risk management. Sci. Total Environ. 408 (20), 4319-4327.

The Times. 1992. Exemplary damages in public nuisance (AB v South West Water Services Ltd [1993] QB 507). London.

Ullsten, O., Speth, J.G., Chapin, F.S., 2004. High-latitude sustainability. AMBIO 33 (6), 343-343.

United States Environmental Protection Agency. 2007. Guidance for Preparing Standard Operating Procedures (SOPs), EPA/600/B-07/001.

Westrell, T., Andersson, Y., Stenström, T.A. 2006. Drinking water consumption patterns in Sweden. J. Water Health 4(4), 511-22.

Winston, G., Leventhal, A., 2008. Unintentional drinking-water contamination events of unknown origin: surrogate for terrorism preparedness. J. Water Health 6 (Suppl. 1), 11-19.

Wu, S., Hrudey, S., French, S., Bedford, T., Soane, E., Pollard, S., 2009. A role for human reliability analysis (HRA) in preventing drinking water incidents and securing safe drinking water. Water Res. 43 (13), 3227-3238.

Xinhua News Agency. 2005. Available at: http://www.gov.cn/yjgl/2005-11/28/content_111595.htm (accessed 19/04/2013).

Xinhua News Agency. 2007. Available at: http://news.xinhuanet.com/english/2007-07/04/content_6324991.htm (accessed 19/04/2013).

Xinhua News Agency. 2009. Available at: http://news.xinhuanet.com/english/2009-07/29/content_11791507.htm (accessed 19/04/2013).

Zeng, S.X., Meng, X.H., Zeng, R.C., Tam, C.M., Tam, V.W.Y., Jin, T. 2011. How environmental management driving forces affect environmental and economic performance of SMEs: a study in the Northern China district. J. Clean Prod. 19 (13), $1426-1437$.

Zhang, X.J., Chen, C., Ding, J.Q., Hou, A.X., Li, Y., Niu, Z.B., Su, X.Y., Xu, Y.J., Laws, E.A. 2010. The 2007 water crisis in Wuxi, China: analysis of the origin. J. Hazard Mater. 182 (1-3), 130-135. 